\title{
Factors Effecting Trading Volume: A Test of Mixed Distribution Hypothesis
}

\author{
Izz Eddien N. Ananzeh ${ }^{1}$ \\ ${ }^{1}$ Faculty of Administrative and Financial Sciences, Philadelphia University, Amman, Jordan \\ Correspondence: Izz Eddien N. Ananzeh, Faculty of Administrative and Financial Sciences, Philadelphia University, \\ Amman, Jordan.
}

Received: September 8, 2015

Accepted: October 8, $2015 \quad$ Online Published: October 13, 2015

doi:10.5430/ijfr.v6n4p207

URL: http://dx.doi.org/10.5430/ijfr.v6n4p207

\begin{abstract}
This paper investigates the empirical relationship between trading volume and conditional volatility using data from Amman Stock Exchange (ASE) within the framework of Mixed Distribution Hypothesis (MDH). Our sample covered 27 securities, which is most active stocks traded for the period span from 2002 to 2012. Generalized Autoregressive Conditional Heteroskedasticity $(\mathrm{GARCH}) \mathrm{k}$ Exchange model employed in order to test the persistence in the volatility of stock returns. Our results confirm positive and strong relationship between trading volume for individual stocks and conditional volatility of returns. Moreover, the degree of volatility persistence reduced through the process of adding the contemporaneous volume into the conditional variance equation of GARCH model, and this is according to the predictions of the Mixture of Distributions Hypothesis (MDH).
\end{abstract}

Keywords: conditional volatility, trading volume, volatility persistence, mixture of distribution hypothesis, Generalized Autoregressive Conditional Heteroskedasticity (GARCH)

\section{Introduction}

Financial markets play a key role in achieving financial stability, where the performance of these markets reflects the performance of the economy in general.

Empirical research on stock markets focus on stock prices and their behavior over times. However, depending on some undesirable stochastic characteristics for prices of stocks specifically non-stationary the former researchers focus their effort on stock returns rather than stock prices.

The changing in the stock returns may occur if the trading volume is positive therefore, the changing in the trading volume reflects mainly the available pertinent information that perceived by the market.

Generally, the stocks return reflect the expectation of the investors about future performance of any firm, the investors adapt their expectation about the future returns depending on the new information arriving, and the interpretation of this information different from one investor to another.

The expectations of the market for future stocks return volatility play an essential role, and the characteristics of this volatility have been one of the main topics tested in literature of finance.

The first attempt to make a link between stock returns and trading volume came from Epps (1975), and Karpoff $(1986,1987)$ by introducing a models to predict an asymmetric relationship between stock returns and trading volume. However, we must know that the models also related to how information's flow to the market.

The first model explained the linking between trading volumes, price changes, and the rate of the information flow was Mixture of Distributions Hypothesis (MDH). MDH model used to explain the presence (ARCH) Autoregressive Conditional Heteroscedasticity effects.

stock prices one of the financial time series often show the phenomena of volatility clustering" as the arrival of dissimilar information from different sources such as economic news and events, and that have a big impact on the time series pattern of stock prices. Therefore, financial time series in most cases behave such a way that does not conform to the normality distribution. Hence, the volatility observed in the market is a natural application for the autoregressive conditional heteroskedasticity (ARCH).To observe this phenomena, ARCH model introduced by Engle (1982) and Bollerslev (1986) generalized ARCH (GARCH) model is used. The GARCH specification allows the current conditional variance to be a function of past conditional variances" (Ahmed et al, (2005), p146). 
The Autoregressive Conditional Heteroscedasticity (ARCH) models forecast future volatility of stock returns given only information on lagged return innovations.

There are few studies conducted on emerging markets as opposed to a lot that conducted on developed markets.

The contributions of this paper on the literature through investigation the relation between return volatility and trading volume in the Amman stock exchange (ASE), by utilizing relatively more recent database for individual stocks instead of a general index, which mostly utilized in previous studies.

The rest of our paper: literature review presented in Section 2, Section 3 present methodology of the study, our empirical finding presented in Section 4, and conclusion presented in Section 5.

\section{Literature Review}

The expectations of the market about the volatility of future stock returns play a crucial role in the literature of finance.

ARCH model including GARCH which Stipulated by Bollerslev (1986), forecast the volatility of future return only given information's on lagged return innovations, the GARCH modeling power came from their effectiveness in capturing volatility clustering and persistence.

Several studies examined the relationship between trading volume and stock returns volatility since 1970's, and many of them provide an evidence of significant positive contemporaneous correlation between returns volatility, and trading volume as suggested by Mixture of Distributions Hypothesis (MDH) (Clark, 1973; Epps and Epps ,1976;Tauchen and Pitts, 1983; Karpoff, 1987; Brailsford ,1996; Alsubaie and Najand, 2009) and others.

Schwert (1989), present an evidence for a positive relationship between current and lagged volume growth rates and estimated volatility using VAR models. In the same line Lamoureux and Lastrapes (1990) have shown that the presence of a positive conditional volume-volatility relationship in models with (GARCH) type volatility specifications and Gaussian errors, and the same result reported by Gallant et al. (1992), Bessembinder and Seguin (1993), and Choi et al, 2012.

Bivariate GARCH framework also used to examine the interrelated characteristics of Volume and volatility data. As discussed by Bollerslev et al. (1988), and Engle et al. (1984).

Sharma et al. (1996), considered an extension to the Lamoureux and Lastrapes (1990) by investigate the relationship between trading volume and the returns volatility through employing GARCH $(1,1)$ model, and this study conducted on NYSE for the period 1986-1989. The result of Sharma et al. (1996) suggests through explaining the GARCH effect that the volume contribute significantly positive, and didn't eliminate GARCH effect.

In the emerging markets, numerous studies conducted to examine the relation between trading volume and returns volatility. Many of these studies provide supporting to Mixture of Distributions Hypothesis, for instance, Bralisford (1996), and Pyuna et al. (2000) reach the same result that we can reduce the degree of volatility persistence through the way of adding or insert current trading volume to the equation of conditional variance.

Oral (2012) conduct his study on Istanbul Stock Exchange, and his finding conclude that the trading volume estimation are positive and significant. In another side, Ahmed et al. (2005), conducting his study on Kuala Lumpur Stock Exchange, for the period span from 1990 to 2000, results show that the persistence of the volatility does not disappear when including trading volume in the model as an explanatory variable.

On another side, in case of our region MEANA markets, the study of Al-Jafari and Tliti ( 2013) came to clarify the relation between returns of stocks and the trading volume in Amman Stock Exchange for the period span from 2006-2011. The results of the study point out for insignificant relationship between stock returns and trading volume for banking sector index, and for Jordanian commercial banks the results point out significant relationship between trading volume and volatility.

Enormous empirical studies present evidence on relationship between returns volatility and trading volume for developed and emerging markets, but in case of our country Jordan current literature does not provide sufficient evidence for the relationship[ between returns volatility and trading volume. Therefore, this paper came in specific to fills the gap through investigating the relationship between stock returns volatility and trading volume in Amman Stock Exchange for period span from 2002 to 2012, by employing GARCH methodology .

\section{Methodology and Data}

Our sample period spans from January 2002 to October 2012, the data set made up of daily stock returns and volume series of 27 companies traded in ASE. 
The firms in the sample selected randomly with different size and trading volume. It is a logical way to see if the results obtained from the analysis of trading volume-return volatility differ through the firms with different trading volume.

The following formula used to calculate the returns of stock:

$$
R E_{t}=\operatorname{Ln}\left(r_{t} / r_{t-1}\right) * 100
$$

$R E_{t}$ : represent the return of the individual stock for day $t, r_{t}$ daily closing price for share at time $t$ in ASE, and the firms included in the tested sample presented in Appendix 1.

The trading volume calculated by the following formula:

$$
T V_{t}=\operatorname{Ln}\left(V_{t} / V_{t-1}\right) * 100
$$

$T V_{t}$ : represent the trading volume of the individual stock for day $t, V_{t} \mathrm{t}$ is daily closing volume traded at time $t$ in ASE.

Assets return behavior many hypotheses have been tried to explain it since Engle (1982),

Autoregressive conditionally heteroscedastic (ARCH) model introduced by Engle in 1982, in which at time $t$ the conditional variance is modeled as a linear function of past squared residuals. Bolerslev (1986) extended the work of Engle (1982), by generalizing the ARCH model, and called it Generalized Autoregressive Conditional Heteroscedasticity (GARCH) process. We employ GARCH methodology to investigate or examine the relation between trading volume and stock returns volatility on Amman Stock Exchange (ASE) for individual stocks.

Firstly, we are going to estimate the $\operatorname{GARCH}(1,1)$ model:

$$
\begin{gathered}
R E_{t}=\mu+\sum_{i=1}^{p} \delta_{i} r_{t-i}+\ell_{t}+\sum_{j=1}^{q} \gamma_{j} \ell_{t-j} \\
\ell_{t} \mid L_{t-1} \sim N\left(0, \delta_{t}^{2}\right) \\
\delta_{t}^{2}=\varphi+\alpha \ell_{t-1}^{2}+\beta \delta_{t-1}^{2}
\end{gathered}
$$

Where $R E_{t}$ illustrate the return in day $t$, and $L_{t-1}$ represent the set of the informational correspond to all available information at $t-1$.

$\alpha$ and $\beta$ : represent the coefficient of ARCH and GARCH, $\alpha+\beta$ measures the degree of persistence for the conditional volatility, The persistence degree determined by the magnitude or the amount of the sum $\alpha+\beta$ coefficients, and if the sum of coefficients closer to 1 this mean more shocks to volatility persist.

In order to test empirically the Mixture of Distributions Hypothesis (MDH), and to examine the relationship which is contemporaneous between the trading volume of stocks, and conditional volatility of stock returns issued from GARCH $(1,1)$ model. We include trading volume $T V_{t}$ as exogenous explanatory variable in the conditional variance (equation 4 ) as a representative for information arrival:

$$
\delta_{t}^{2}=\varphi+\alpha \ell_{t-1}^{2}+\beta \delta_{t-1}^{2}+\eta T V
$$

Where $T V_{t}$ : represent the trading volume of the individual stock for day ${ }^{t}$, if $\eta$ is statistically significant this evidence for contemporaneous relationship between trading volume and. 
We expect, if $\mathrm{MDH}$ is valid the coefficients $\eta$ should be positive and significant, and $\alpha+\beta$ would be significantly smaller than when $T V_{t}$ is not included. In another term, the adding variable $\left(T V_{t}\right)$ should be statistically significant and positive, as well as remove the GARCH effect in returns of stocks.

Before of the estimation process of the models coefficient, we must conduct a preliminary tests for time series studied via the stationary, and normality tests.

\section{Empirical Results}

Our investigation started with some basic descriptive analysis of daily return series for each firms listed in the sample that presented in Table 1.

Table 1 displays the descriptive statistics for all individual stocks. The mean returns are positive except four companies; (Arab Union International Insurance, and Jordan Investment Trust, Union Investment Corporation; Arab Center for Pharm \& Chemicals). The mean returns ranges between $-0.7 \%$ to $15.20 \%$, and the range of standard deviation was between $2.240 \%$ and $11.30 \%$.

We conduct Jarque-Bera test, In order to inspect the normality for stock return series, and the results show that the distribution of stocks return that included in the sample has a fat tails, and peaks are sharper than the normal distribution. In addition, excess kurtosis for all the stocks returns series, which is consistent or harmonious of the presence of GARCH effects. This result as well as subsequent tests results supports our methodology by using GARCH model to study the relationship between volume-volatility. Thus, we will reject the null hypothesis of normality for all stocks series by Jarque-Bera statistics.

Table 1. Descriptive statistics of stock returns for individual firms

\begin{tabular}{|c|c|c|c|c|c|}
\hline Stock & Mean\% & $\begin{array}{l}\text { Standard } \\
\text { Deviation \% }\end{array}$ & Skewness & $\begin{array}{l}\text { Excess } \\
\text { Kurtosis }\end{array}$ & $\begin{array}{l}\text { Jarque-Bera } \\
\text { (JB) }\end{array}$ \\
\hline ARBBNK & 0.1520 & 3.010 & 0.320 & 4.620 & $2760.1 *$ \\
\hline THTBF & 0.1351 & 3.120 & 0.230 & 7.552 & $2493.4 *$ \\
\hline JAHLI & 0.1460 & 3.620 & -0.313 & 7.650 & $2433.3 *$ \\
\hline MEIC & 0.0500 & 5.030 & 0.1120 & 5.541 & $3277.2^{*}$ \\
\hline JFRI & 0.110 & 3.330 & 0.2300 & 11.650 & $2888.10^{*}$ \\
\hline HLI & 0.0900 & 3.030 & 0.110 & 6.351 & $2080.82 *$ \\
\hline AUII & -0.0180 & 5.330 & 0.140 & 7.653 & 1780.81 \\
\hline ARAS & 0.0330 & 3.290 & 0.139 & 4.431 & 1134.40* \\
\hline AAI & 0.0030 & 6.0300 & 0.120 & 6.9902 & 7618.10* \\
\hline INVHO & 0.1230 & 4.310 & 0.260 & 5.770 & $265.520^{*}$ \\
\hline AMWAL & 0.1420 & 3.030 & 0.098 & 6.8801 & $702.910 *$ \\
\hline JOMCO & 0.1240 & 3.440 & 1.080 & 8,5502 & $6.9981^{*}$ \\
\hline DARJO & 0.0120 & 11.30 & 0.190 & 5.7703 & $407.10^{*}$ \\
\hline JOITRU & -0.0330 & 4. 250 & 1.000 & 8.002 & $33.461 *$ \\
\hline UNINV & -0.0300 & 4.030 & 0.1701 & 7.320 & $2287.60^{*}$ \\
\hline UNLDC & 0.110 & 3.450 & 0.410 & 6.653 & $8642.1^{*}$ \\
\hline SPICO & 0.0300 & 5.020 & 0.230 & 7.652 & $1059.20 *$ \\
\hline REDEV & 0.160 & 3.030 & 0.120 & 7.540 & $1107.20^{*}$ \\
\hline REIP & 0.1430 & 3.460 & 0.4101 & 6.9981 & $1260.10^{*}$ \\
\hline JIIP & 0.1700 & 4.250 & 0.0901 & 22.770 & $140.53^{*}$ \\
\hline ITIHSC & 0.030 & 3.300 & 0.345 & 4.650 & $175.62 *$ \\
\hline JETT & 0.0204 & 5.040 & 0.160 & 7.220 & $5.143 * * *$ \\
\hline JTELE & 0.001 & 4.020 & 0.2100 & 8.542 & $822.01 *$ \\
\hline JPRES & 0.0014 & 3.140 & -0.070 & 4.351 & $1289.10^{*}$ \\
\hline JOPTR & 0.00250 & 3.410 & 0.0320 & 6.771 & $83.342 *$ \\
\hline JPHM & 0.0070 & 2.240 & 0.0110 & 5.650 & $67.391^{*}$ \\
\hline APHC & -0.007 & 3.140 & 0.140 & 7.650 & $5261.20 *$ \\
\hline
\end{tabular}

Note: The Jarque-Bera (JB) is the test statistic test for the null hypothesis of normality in sample returns distributions. $*, * *$, and $* * *$ refer to $1 \%, 5 \%, 10 \%$ significant statistically respectively in this table and the tables below. 
In order to examine the Unit Root we employ two statistics, augmented Dickey-Fuller Test (ADF), and Kwiatkowski-Phillips-Schmidt-Shin (KPSS) test.

The results presents in Table 2, shows that ADF test verify that A stationary series has significant, and insignificant in KPSS test.

We apply Q statistic in order to check serial correlation, and the results as shown in Table 2 verify that the all series display significant serial correlation. Consequently the rate of the information arrival for the stocks measured by the trading volume is significantly serially correlated, and the two tests of the Unit Root confirms stationary for all ser in the sample at $1 \%$.

Table 2. Results of unit root tests, and Autocorrelation coefficients of returns

\begin{tabular}{llll}
\hline Stock & ADF & KPSS & Q(12) \\
\hline ARBBNK & -3.441 & 1.430 & $0.653^{*}$ \\
\hline THTBF & -3.450 & 0.992 & $0.431^{*}$ \\
\hline JAHLI & -4.662 & 1.771 & $0,322^{*}$ \\
\hline MEIC & -3.650 & 2.322 & $0.453^{*}$ \\
\hline JFRI & -5.230 & $3.090^{*}$ & $0.641^{*}$ \\
\hline HLI & -3.870 & 1.430 & $0,582^{*}$ \\
\hline AUII & -3.323 & 1.233 & $0.470^{*}$ \\
\hline ARAS & -4.322 & 0.981 & $0.033^{*}$ \\
\hline AAI & -5.461 & 2.321 & $0.261^{*}$ \\
\hline INVHO & -5.542 & 1.351 & $0.331^{*}$ \\
\hline AMWAL & -3.343 & 2.010 & $0.663^{*}$ \\
\hline JOMCO & -6.883 & 1.881 & $0.233^{*}$ \\
\hline DARJO & -4.320 & 2.650 & $0.498^{*}$ \\
\hline JOITRU & -3.650 & 0.880 & $0.583^{*}$ \\
\hline UNINV & -5.351 & 0.850 & $0.380^{*}$ \\
\hline UNLDC & -3.430 & 1.430 & $0.521^{*}$ \\
\hline SPICO & -4.352 & 0.751 & $0.482^{*}$ \\
\hline REDEV & -7.901 & 2.540 & $0.431^{*}$ \\
\hline REIP & -4.230 & 0.971 & $0.652^{*}$ \\
\hline JIIP & -3.442 & 0.881 & $0.233^{*}$ \\
\hline ITIHSC & -3.120 & 0.720 & $0.580^{*}$ \\
\hline JETT & -5.991 & 1.990 & $0.291^{*}$ \\
\hline JTELE & -6.730 & 2.998 & $0.650^{*}$ \\
\hline JPRES & -4.233 & 1.440 & $0.540^{*}$ \\
\hline JOPTR & -4.684 & 0.810 & $0.431^{*}$ \\
\hline JPHM & -3.430 & 0.961 & $0.054^{*}$ \\
\hline APHC & -6.771 & 2.220 & \\
\hline and KPSS & & & \\
\hline
\end{tabular}

Note: The ADF and KPSS tests contain a constant term, and according to the Akaike information criterion (AIC) the augmentations of DF tests are determined. Critical values of ADF and KPSS tests at 1\% level are -3.434 and 0.738 , respectively. Q (12), refer to the Ljung-Box statistic up to 12 lags.

Empirically in order to examine the relationship between returns conditional volatility and trading volume. Firstly, we are going to estimate $\operatorname{GARCH}(1,1)$ model by excluding the volume (equations 3 and 4 ) to model the dynamics way of conditional volatility. Table 3 reports the parameters estimations of model. 
Table 3. GARCH $(1,1)$ models estimation results

\begin{tabular}{|c|c|c|c|c|}
\hline Stock & $\alpha$ & $\beta$ & $\alpha+\beta$ & AIC \\
\hline ARBK & $0.061 *$ & $0.863^{*}$ & 0.930 & -4.10 \\
\hline THTBF & $0.133^{*}$ & $0.522^{*}$ & 0.650 & -4.31 \\
\hline JAHLI & $0.210 *$ & $0.561 * *$ & 0.760 & -4.21 \\
\hline MEIC & $0.181 *$ & $0.891 *$ & 1.060 & -4.30 \\
\hline JFRI & $0.130^{*}$ & $0.630 *$ & 0.771 & -4.81 \\
\hline HLI & $0.110 *$ & $0.761^{*}$ & 0.872 & -4.10 \\
\hline AUII & $0.151 *$ & $0.891^{*}$ & 1.030 & -4.09 \\
\hline ARAS & $0.053^{*}$ & $0.878^{*}$ & 0.93 & -4.25 \\
\hline AAI & $0.166^{*}$ & $0.882^{*}$ & 1.048 & -4.18 \\
\hline INVHO & $0.298 *$ & $0.634^{*}$ & 0.928 & -4.38 \\
\hline AMWAL & $0.168 *$ & $0.713^{*}$ & 0.882 & -4.64 \\
\hline JOMCO & $0.197 *$ & $0.696^{*}$ & 0.897 & -4.22 \\
\hline DARJO & $0.203^{*}$ & $0.667^{*}$ & 0.867 & -4.79 \\
\hline JOITRU & $0.097 *$ & $0.741^{*}$ & 0.842 & -4.22 \\
\hline UNINV & $0.176^{*}$ & $0.653^{*}$ & 0.827 & -4.13 \\
\hline UNLDC & $0.142 *$ & $0.787^{*}$ & 0.933 & -4.57 \\
\hline SPICO & $0.233 *$ & $0.672^{*}$ & 0.911 & -4.67 \\
\hline REDEV & $0.126^{*}$ & $0.537^{*}$ & 0.670 & -4.53 \\
\hline REIP & $0.033^{*}$ & $0.913^{*}$ & 0.951 & -4.01 \\
\hline JIIP & $0.188^{*}$ & $0.697 * *$ & 0.891 & -4.16 \\
\hline ITIHSC & $0.112^{*}$ & $0.808^{*}$ & 0.921 & -4.48 \\
\hline JETT & $0.218^{*}$ & $0.607^{*}$ & 0.831 & -4.96 \\
\hline JTELE & $0.103 *$ & $0.710^{*}$ & 0.820 & -3.81 \\
\hline JPRES & $0.115^{*}$ & $0.775^{*}$ & 0.890 & -4.60 \\
\hline JOPTR & $0.150 *$ & $0.802^{*}$ & 0.951 & -4.23 \\
\hline ЈРНМ & $0.226 *$ & $0.677^{*}$ & 0.911 & -4.10 \\
\hline APHC & $0.080 *$ & $0.831^{*}$ & 0.910 & -4.51 \\
\hline
\end{tabular}

Table 3 present the $\alpha, \beta$ estimated parameters from estimation $\operatorname{GARCH}(1,1)$ model to valuate the volatility persistence degree, also Akaike Information Criterion (AIC) employed in order to display a basis for GARCH models comparison. ARCH and GARCH estimated coefficients $\alpha, \beta$ are statistically significant at $1 \%$ level. The summations of coefficient $\alpha+\beta$ are high in general and close to one for the all stocks in the sample. This is an evidence for a high degree in volatility persistence.

Table 4. GARCH $(1,1)$ models estimation with trading volume results

\begin{tabular}{llllll}
\hline Stock & $\alpha$ & $\beta$ & $\eta \times 10000$ & $\alpha+\beta$ & AIC \\
\hline ARBBNK & $0.361^{*}$ & $0.341^{*}$ & $2.120^{*}$ & 0.702 & -4.23 \\
\hline THTBF & $0.431^{*}$ & $0.293^{*}$ & $1.540^{*}$ & 0.722 & -4.11 \\
\hline JAHLI & $0.376^{*}$ & $0.325^{*}$ & $0.753^{*}$ & 0.701 & -4.21 \\
\hline MEIC & $0.345^{*}$ & $0.660^{*}$ & $0.896^{*}$ & 0.941 & -4.30 \\
\hline JFRI & $0.301^{*}$ & $0.410^{*}$ & 0.007 & 0.710 & -4.31 \\
\hline HLI & $0.276^{*}$ & $0.531^{*}$ & $-0.097^{* *}$ & 0.811 & -4.50 \\
\hline AUII & $0.320^{*}$ & $0.655^{*}$ & $0.137^{*}$ & 0.970 & -4.20 \\
\hline ARAS & $0.223^{*}$ & $0.542^{*}$ & $0.797^{*}$ & 0.766 & -4.31 \\
\hline AAI & $0.340^{*}$ & $0.650^{*}$ & $-0.103^{* *}$ & 0.985 & -4.10 \\
\hline
\end{tabular}




\begin{tabular}{llllll}
\hline INVHO & $0.053^{*}$ & $0.401^{*}$ & $0.323^{*}$ & 0.455 & -4.30 \\
\hline AMWAL & $0.233^{*}$ & $0.481^{*}$ & $0.270^{*}$ & 0.715 & -4.32 \\
\hline JOMCO & $0.122^{*}$ & $0.396^{*}$ & 0.135 & 0.520 & -4.41 \\
\hline DARJO & $0.255^{*}$ & $0.440^{*}$ & $4.653^{*}$ & 0.890 & -4.80 \\
\hline JOITRU & $0.267^{*}$ & $0.512^{*}$ & $0.0542^{*}$ & 0.780 & -4.32 \\
\hline UNINV & 0.350 & $0.423^{*}$ & $7.986^{*}$ & 0.768 & -4.30 \\
\hline UNLDC & $0.312^{*}$ & $0.558^{*}$ & $0.542^{*}$ & 0.871 & -4.61 \\
\hline SPICO & $0.097^{*}$ & $0.440^{*}$ & 0.007 & 0.538 & -4.95 \\
\hline REDEV & $0.296^{*}$ & $0.310^{*}$ & 0.036 & 0.605 & -4.50 \\
\hline REIP & $0.203^{*}$ & $0.682^{*}$ & $0.875^{*}$ & 0.886 & -4.21 \\
\hline JIIP & $0.097^{*}$ & $0.467 *$ & $0.553^{*}$ & 0.565 & -4.80 \\
\hline ITIHSC & $0.282^{*}$ & $0.578^{*}$ & $0.102^{* *}$ & 0.861 & -4.50 \\
\hline JETT & $0.075^{*}$ & $0.377^{*}$ & $0.875^{*}$ & 0.453 & -4.22 \\
\hline JTELE & $0.273^{*}$ & $0.480^{*}$ & $6.441^{*}$ & 0.761 & -4.75 \\
\hline JPRES & $0.285^{*}$ & $0.545^{*}$ & $0.040^{*}$ & 0.831 & -4.50 \\
\hline JOPTR & $0.320^{*}$ & $0.572^{*}$ & $0.770^{*}$ & 0.887 & -4.90 \\
\hline JPHM & $0.100^{*}$ & 0.007 & $0.341^{*}$ & 0.557 & -4.71 \\
\hline APHC & $0.250^{*}$ & $0.601 *$ & $0.642^{*}$ & 0.852 & -4.81 \\
\hline & & & & &
\end{tabular}

This degree of volatility persistence with high rate for all individual stocks on ASE reflects the phenomenon of the presence or existence volatility clustering. The persistence and the time varying of Conditional volatility are mainly the serial correlation results in the process of information arrival as proposed by the MDH where volume is a proxy. In the process of examining or testing last hypo, we add contemporaneous trading volume to the equation of conditional variance of GARCH $(1,1)$ as shown in equation 5. Table (4) report the result of estimated parameters of Equation 4 including trading volume.

The coefficients $\eta$ of trading volume coefficients $\eta$ are statistically significant for 23 firms out of 27 cases at 5\% level at least. These results present a positive strong contemporaneous relationship between stock returns volatility and trading volume.

This outcome is consequently a result of the joint or common dependence between e volume and the volatility to an unobservable directing variable explaining the daily rate of information flow as assumed by MDH. Which assumed that when the new information publishing is contemporaneous the immediate reaction of different investor on its arrival on the market drive or lead to a positive contemporaneous relations volume and volatility.

This is an indicator for of possibility outstanding of exist other variables besides trading volume that can contribute the conditional heteroskedasticity in stock return series on the Amman stock exchange financial market.

These results consistent with results of a many studies, for instance Lamoureux and Lastrapes (1990), Pyun (2000), Huang and Yang (2001), Bohl and Henke (2003), Kumar et al. (2010), Louhichi (2011), and Celik (2013). In emerging markets Huang and Yang (2001) have found similar results in Taiwan.

For stock volatility at minimum, a part of the persistence can explain away by information arrivals. In this line, by comparing our finding with the empirical finding of developed markets, our findings on ASE do not support the existence Mixture of Distributions Hypothesis.

There are several reasons might leading to this result.

1). The content and the pattern of daily information arrivals of trading volume may be different in the ASE. 2). The price limitation imposed by ASE. 3). The number of transactions might be a better proxy instead of trading volume to represent daily information arrivals.

\section{Conclusion}

The aim of this paper to investigate the relationship between trading volume and conditional volatility for 27 stocks in Amman Stock Exchange for the period 2002-2012, in order to test the validation of Mixed Distribution 
Hypothesis (MDH). Generlized Autoregressive Conditional Heteroskedasticity (GARCH) model employed in order to test the persistence in the volatility of stock returns. Our results confirm positive and strong relationship between trading volume for individual stocks and conditional volatility of returns. Moreover, the degree of volatility persistence reduced through the process of adding the contemporaneous volume into the conditional variance equation of GARCH model, and this is according to the predictions of the Mixture of Distributions Hypothesis (MDH).

\section{References}

Ahmed, H. J. A., Hassan, A., \& Nasir, A. M. D. (2005). The Relationship between Trading Volume, Volatility and Stock Market Returns: A Test of Mixture of Distribution Hypothesis for Pre and Post Crises on Kuala Lumpur Stock Exchange. Investment Management and Financial Innovation, 3, 146-158.

Al-Jafari, M., \& Tliti, M. (2013). An Empirical Investigation of the Relationship between Stock Return and Trading Volume: Evidence from the Jordanian Banking Sector. Journal of Applied Finance \& Banking, 3(3), 45-64.

Alsubaie, A., \& Najand, M. (2009). Trading volume, time-varying conditional volatility, and asymmetric volatility spillover in the Saudi stock market. Journal of Multinational Financial Management, 19, 139-159. http://dx.doi.org/10.1016/j.mulfin.2008.09.002

Ananzeh, I., Jdaitawi, Q., \& Al-Jayousi, A. (2013). Relationship between Market Volatility and Trading Volume: Evidence from Amman Stock Exchange. International Journal of Business and Social Science, 4(16), 188-198.

Andersen, T G. (1996). Return Volatility and Trading Volume: An Information Flow Interpretation of Stochastic Volatility. Journal of Finance, 51, 169-204. http://dx.doi.org/10.1111/j.1540-6261.1996.tb05206.x

Balaban, E. (1995). Day of the week effects: new evidence from an emerging stock market. Applied Economics Letters, 2, 139-143. http://dx.doi.org/10.1080/135048595357465

Belhaj, F., \& Abaoub, E. (2013). A Generalized Autoregressive Conditional Heteroskedasticity, Examination of the Relationship between Trading Volume, and Conditional Volatility in the Tunisian Stock Market: Evidence for the Information Flow Paradigm. International Journal of Economics and Financial Issues, 5(2), 354-364.

Bessembinder, H., \& Seguin, P. J. (1993). Price volatility, trading volume, and market depth: Evidence from futures markets. Journal of Financial and Quantitative Analysis, 28, 21-39. http://dx.doi.org/10.2307/2331149

Bohl, M., \& Henke, H. (2003). Trading volume and stock market volatility: The Polish case. International Review of Financial Analysis, 153, 1-13. http://dx.doi.org/10.1016/s1057-5219(03)00066-8

Bollerslev, T. (1986). Generalized autoregressive conditional heteroskedasticity. Journal of Econometrics, 37, 307-27. http://dx.doi.org/10.1016/0304-4076(86)90063-1

Bollerslev, T. (1988). On the correlation structure for the generalized autoregressive conditional heteroskedastic process. Journal of Time Series Analysis, 9, 121-31. http://dx.doi.org/10.1111/j.1467-9892.1988.tb00459.x

Brailsford, T. J. (1994). The Empirical relationship between Trading Volume, Returns and Volatility. Research Paper, Department of Accounting and Finance, University of Melbourne, No. 1994-01, pp.1-33.

Brailsford, T. J. (1996). The Empirical Relationship Between Trading Volume and Returns Volatility. Accounting and Finance, 36, 89-111. http://dx.doi.org/10.1111/j.1467-629X.1996.tb00300.x

Celik, S. (2013). New Evidence on the Relation between Trading Volume and Volatility. Business and Economic Research, 3(1).

Choi, K. H., Jiang, Z. H., Kang, S. H., \& Yoon, S. M. (2012). Relationship between Trading Volume and Asymmetric Volatility in the Korean Stock Market. Modern Economy, 3(5), 584-589. http://dx.doi.org/10.4236/me.2012.35077

Clark, P. K. (1973). A Subordinated Stochastic Process Model with Finite Variance for Speculative Prices. Econometrica, 41, 135-156. http://dx.doi.org/10.2307/1913889

Engle, R. F. (1982). Autoregressive Conditional Heteroscedasticity with Estimates of the Variance of United Kingdom Inflation. Econometrica, 50, 987-1008. http://dx.doi.org/10.2307/1912773

Engle, R., Granger, C. W. J. \& Kraft, D. (1984). Combining competing forecasts of inflation using a bivariate ARCH model. Journal of Economic Dynamics and Control, 8, 151-165. http://dx.doi.org/10.1016/0165-1889(84)90031-9 
Epps, T. W. (1975). Security price changes and transaction volumes: Theory and evidence. The American Economic Review, 65(4).

Epps, T., \& Epps, M. (1976). The stochastic dependence of stochastic price changes, and transaction volume: Implications for the mixture of distribution hypothesis. Econometrica, 44, 305-321. http://dx.doi.org/10.2307/1912726

Gallant, R. A., Rossi, P. E., \& Tauchen, G. (1992). Stock Prices and Volume. Review of Financial Studies, 5, 199-242. http://dx.doi.org/10.1093/rfs/5.2.199

Karpoff, J. M. (1986). A Theory of Trading Volume. Journal of Finance, 41, 1069-87. http://dx.doi.org/10.1111/j.1540-6261.1986.tb02531.x

. (1987). The relation between price changes, and trading volume. Journal of Financial and Quantitative Analysis, 22(1), 109-126. http://dx.doi.org/10.2307/2330874

Kumar, \& Pabdey. (2010). Price and Volatility Spillovers Across North American, European and ASIAN Stock Markets. International Review of Financial Analysis, 19(1).

Lamoureux, C. G., \& Lastrapes, W. D. (1990). Heteroskedasticity in Stock Return Data: Volume versus GARCH Effects. Journal of Finance, 45, 221-229. http://dx.doi.org/10.1111/j.1540-6261.1990.tb05088.x

Lamoureux, C. G., \& Lastrapes, W. D. (1994). Endogenous Trading Volume and Momentum in Stock-Return Volatility. Journal of Business \& Economic Statistics, 12, 253-260.

Louhichi, W. (2011). What drives the volume-volatility relationship on Euronext Paris. International Review of Financial Analysis, 20, 200-206. http://dx.doi.org/10.1016/j.irfa.2011.03.001

Oral, E. (2012). An Empirical Analysis of Trading Volume and Return Volatility Relationship on Istanbul Stock Exchange National-100 Index. Journal of Applied Finance and Banking, 2(5), 149-158.

Sabri, N. R. (2004). Stock Return Volatility and Market Crisis in Emerging Economies. Review of Accounting and Finance, 3, 59-83. http://dx.doi.org/10.1108/eb043408

Salman, F. (2002). Risk-return-volume relationship in an emerging stock market. Applied Economics Letters, 9, 549-552. http://dx.doi.org/10.1080/13504850110105727

Schwert, G. W. (1989). Tests for unit roots: A Monte Carlo investigation. Journal of Business and Economic Statistics, 2, 147-159.

Sharma, J. L., Mougoue, M., \& Kamath, R. (1996). teroscedasticity in stock market indicator return data: volume versus GARCH effects. Applied Financial Economics, 6, 337-342. http://dx.doi.org/10.1080/096031096334132

Tauchen, G., \& Pitts, M. (1983). The Price Variability-Volume Relationship on Speculative Markets. Econometrica, 51, 485-505. http://dx.doi.org/10.2307/1912002 
Appendix 1. List of companys included in the sample

\begin{tabular}{|c|c|}
\hline COMPANY'S NAME & SYMBOL \\
\hline ARAB BANK & ARBK \\
\hline THE HOUSING BANK FOR TRADE AND FINANCE & THTBF \\
\hline JORDAN AHLI BANK & JAHLI \\
\hline MIDDLE EAST INSURANCE & MEIC \\
\hline JORDAN FRENCH INSURANCE & JFRI \\
\hline THE HOLY LAND INSURANCE & HLI \\
\hline ARAB UNION INTERNATIONAL INSURANCE & AUII \\
\hline THE ARAB ASSURERS & ARAS \\
\hline AL-AMIN FOR INVESTMENT & AAI \\
\hline INVESTMENT HOUSE FOR FINANCIAL SERVICES & INVHO \\
\hline AMWAL INVEST & AMWAL \\
\hline $\begin{array}{l}\text { JORDANIAN MANAGEMENT } \\
\text { COMPANY }\end{array}$ & JOMCO \\
\hline DARAT JORDAN HOLDINGS & DARJO \\
\hline JORDAN INVESTMENT TRUST & JOITRU \\
\hline UNION INVESTMENT CORPORATION & UNINV \\
\hline UNION LAND DEVELOPMENT CORPORATION & UNLDC \\
\hline SPECIALIZED INVESTMENT COMPOUNDS & SPICO \\
\hline REAL ESTATE DEVELOPMENT & REDEV \\
\hline THE REAL ESTATE \& INVESTMENT PORTFOLIO & REIP \\
\hline JORDAN INTERNATIONAL INVESTMENT CO. & JIIP \\
\hline ITTIHAD SCHOOLS & ITIHSC \\
\hline JORDAN EXPRESS TOURIST TRANSPORT & JETT \\
\hline JORDAN TELECOM & JTELE \\
\hline JORDAN PRESS FOUNDATION/AL-RA'I & JPRES \\
\hline JORDAN PETROLEUM REFINERY & JOPTR \\
\hline THE JORDANIAN PHARMACEUTICAL MANUFACTURING & JPHM \\
\hline ARAB CENTER FOR PHARM.\& CHEMICALS & APHC \\
\hline
\end{tabular}

